\title{
Efektivitas Analgesik Ekstrak Etil Asetat Daun Kersen (Muntingia calabura L.) pada Mencit Putih (Mus musculus) dengan Metode Rangsangan Panas (Hot Plate Method)
}

\section{Effectiveness Analgesic of Ethyl Acetate Extract of Kersen Leaves (Mutingia calabura L.) on White Mice by Heat Stimulation Methods (Hot Plate Method)}

\author{
I Gusti Agung Ayu Kusuma Wardani ${ }^{1 \bullet}$, I Made Agus Sunadi Putra², Ketut Agus Adrianta², \\ Ni Nyoman Wahyu Udayani ${ }^{2}$ \\ 1Program Studi Diploma Tiga Farmasi, Fakultas Farmasi Universitas Mahasaraswati Denpasar, Bali, Indonesia \\ 2Program Studi Sarjana Farmasi, Fakultas Farmasi Universitas Mahasaraswati Denpasar, Bali, Indonesia
}

\begin{abstract}
Abstrak: Bali merupakan salah satu provinsi dengan tingkat penggunaan obat analgesik yang terus meningkat. Penggunaan obat analgesik dalam jangka panjang dapat menimbulkan efek samping. Sehubungan dengan hal tersebut, orientasi masyarakat saat ini telah beralih ke alam, "back to nature" yang membawa masyarakat kembali memanfaatkan bahan alam, termasuk pengobatan dengan tanaman berkhasiat obat. Salah satunya tumbuhan yang berkhasiat sebagai obat analgesik secara empiris yaitu daun kersen (Mutingia calabura L.). Penelitian ini bertujuan untuk mengetahui efektivitas analgesik ekstrak daun kersen pada mencit putih (Mus Musculus). Penelitian ini merupakan penelitian eksperimental dengan menggunakan metode rangsangan panas pada suhu $55^{\circ} \mathrm{C}$. Pada penelitian ini menggunakan hewan uji mencit putih yang dibagi dalam lima kelompok masing-masing terdiri dari 5 ekor mencit. Kelompok kontrol positif diberi asam mefenamat $65 \mathrm{mg} / \mathrm{Kg} \mathrm{BB}$, kelompok kontrol negatif diberi minyak kelapa $25 \mathrm{ml} / \mathrm{Kg} \mathrm{BB}$, kelompok uji diberi ekstrak daun kersen dengan dosis $100 \mathrm{mg} / \mathrm{Kg} \mathrm{BB}, 125$ $\mathrm{mg} / \mathrm{Kg}$ BB dan $150 \mathrm{mg} / \mathrm{Kg}$ BB. Pengujian efek analgesik dilakukan pada menit ke-60. Dari hasil uji Tukey Test menunjukkan bahwa tidak terdapat perbedaan yang signifikan terhadap waktu munculnya respon nyeri antara kelompok kontrol positif dengan kelompok perlakuan (ekstrak dosis $125 \mathrm{mg} / \mathrm{Kg}$ BB dan $150 \mathrm{mg} / \mathrm{Kg} \mathrm{BB}$ ) dengan nilai signifikan secara berturut-turut 0.914 dan 0,996. Berdasarkan hasil penelitian dapat disimpulkan bawah ekstrak etil asetat daun kersen dosis $125 \mathrm{mg} / \mathrm{Kg}$ BB efektif sebagai analgesik pada mencit jantan.
\end{abstract}

Kata Kunci: analgesik, daun kersen, panas

Abstract: Bali is one of the provinces with the increasing use of analgesic drugs. Long-term use of analgesic drugs can cause side effects. In this regard, the current orientation of society has shifted to nature, "back to nature" which brings people back to use natural ingredients, including treatment with medicinal plants. One of the plants that has empirical analgesic properties is cherry leaves (Mutingia calabura L.). This study aims to determine the analgesic effectiveness of cherry leaf extract in white mice (Mus Musculus). This research is an experimental study using the heat stimulation method at a temperature of $55^{\circ} \mathrm{C}$. In this study using white mice as test animals which were divided into five groups each consisting of 5 mice. The positive control group was given mefenamic acid $65 \mathrm{mg} / \mathrm{Kg}$ BW, the negative control group was given coconut oil $25 \mathrm{ml} / \mathrm{Kg} \mathrm{BW}$, the test group was given cherry leaf extract at a dose of $100 \mathrm{mg} / \mathrm{Kg} \mathrm{BW}, 125 \mathrm{mg} / \mathrm{Kg} \mathrm{BW}$ and $150 \mathrm{mg} / \mathrm{Kg} \mathrm{BW}$. The analgesic effect was tested at 60 minutes. The Tukey Test results showed that there was no significant difference in the timing of the emergence of the pain response between the positive control group and the treatment group (extract dosages of $125 \mathrm{mg} / \mathrm{Kg} \mathrm{BW}$ and $150 \mathrm{mg} / \mathrm{Kg} \mathrm{BW}$ ) with significant values, respectively 0.914 and 0.996 . Based on the research results, it can be concluded that the ethyl acetate extract of cherry leaves at a dose of $125 \mathrm{mg} / \mathrm{Kg}$ BW is effective as an analgesic in male mice.

Keywords: COVID-19, Body Resistance, Immunomodulators, Students, Supplements.

\footnotetext{
•email korespondensi: kusumawardani210488@gmail.com
} 


\section{PENDAHULUAN}

Analgetika atau obat penghilang nyeri adalah zat-zat yang mengurangi atau menghalau rasa nyeri tanpa menghilangkan kesadaran. Obat analgesik dapat dibedakan menjadi dua golongan yaitu analgetika perifer (non-narkotik) yaitu obat yang tidak bersifat narkotiik dan tidak bekerja secara sentral dan analgetika narkotik yaitu obat khusus yang digunakan untuk menghilangkan rasa nyeri yang hebat, seperti fractura dan kanker (Tjay dan Rahardja, 2007).

Penggunaan analgesik memiliki beberapa efek samping diataranya: gangguan lambung-usus, kerusakan pada darah, kerusakan hati dan ginjal serta reaksi alergi pada kulit. Efek samping tersebut terjadi apabila penggunaan obat analgesik terlalu lama dan dalam dosis yang tinggi (Tjay dan Rahardja, 2007). Pada penggunaan analgesik opiod dapat mengakibatkan ketergantungan (Jahwa, et.al., 2016).

Salah satunya tumbuhan yang dipercaya berkhasiat untuk mengilangkan rasa nyeri yaitu tumbuhan kersen (Mutingia calabura L.). Tumbuhan kersen merupakan tanaman buah tropis yang mudah ditemukan dan termasuk dalam family Mutingiaceae. Kersen berkhasiat untuk menyembuhkan asam urat, antiseptik, antiinflamasi dan antitumor (Suryaningsih, et.al., 2018). Secara empiris daun kersen merupakan tanaman obat yang sering digunakan oleh masyarakat sebagai obat batuk, penyakit kuning dan asam urat. Berdasarkan hasil penelitian sebelumnya, ekstrak infusa daun kersen memiliki aktivitas sebagai analgesik (Sentat, et.al., 2016).

Senyawa kimia yang terkandung pada daun kersen antara lain flavonoid, alkaloid, tanin dan saponin. Senyawa flavonoid dalam daun kersen diduga memiliki aktivitas sebagai analgesik. Adapun mekanisme kerja senyawa flavonoid yaitu menghambat kerja enzim siklooksigenase sehingga produksi prostaglandin akan menurun dan rasa nyeri akan berkurang atau menghilang. Senyawa flavonoid juga dapat menghambat degranulasi neutrophil sehingga akan menghambat pengeluaran sitokin, radikal bebas serta enzim yang berperan dalam proses peradangan
(Danugroho, et.al., 2014). Berdasasarkan latar belakang diatas perlu dilakukan penelitian mengenai efektivitas ekstrak etil asetat daun kersen sebagai analgesik pada mencit putih dengan metode rangsangan panas.

\section{METODE PENELITIAN}

Rancangan Penelitian. Jenis penelitian yang digunakan adalah penelitian eksprimental dengan rancangan penelitian Randomized Control Group Posttest only Design

Alat. Hotplate, stopwatch, sonde, timbangan analitik, corong Buchner, cawan porselin, mortar dan stamper, blender, dan rotary evaporator

Bahan. Daun kersen diperoleh di Desa Demulih, Kecamatan Susut, Kabupaten Bangli, larutan etil asetat, asam mefenamat, minyak kelapa.

Populasi dan Sampel. Populasi pada penelitian ini adalah mencit putih galur wistar. Sampel yang digunakan dalam penelitian ini adalah mencit putih galur wistar yang memenuhi kriteria inklusi dan eksklusi sebagai berikut:

1. Kriteria inklusi

a. Mencit putih jantan

b. Berat badan 20-30 gram

c. Umur 2-3 bulan

2. Kriteria eksklusi

Yang termasuk kriteria eksklusi dalam penelitian ini adalah mencit yang sakit atau mati dalam penelitian.

Pembuatan Ekstrak Daun Kersen. Pembuatan ekstrak daun kersen dilakukan dengan metode maserasi. Serbuk daun kersen ditimbang sebanyak 200 gram dan dimasukkan ke dalam wadah kaca lalu direndam dengan pelarut etil asetat sebanyak $800 \mathrm{~mL}$ dengan perbandingan 1: 4 selama 5 hari terlindung dari cahaya. Dalam 5 hari perendaman dilakukan pengadukan setiap hari. Setelah 5 hari perendaman, maserat yang didapat disaring dengan menggunakan kertas saring (filtrat 1). Sisa dari ekstrak kembali diesktrak dengan 800 $\mathrm{mL}$ etil asetat selama 2 hari menggunakan kertas saring (filtrat 2). Filtrat 1 dan filtrat 2 dikumpulkan 
lalu diuapkan menggunakan rotary evaporator pada suhu $40^{\circ} \mathrm{C}$ kemudian dikentalkan menggunakan oven sampai menjadi ekstrak kental.

Uji Efektivitas Antiinflamasi Ekstrak Daun Kersen. Mencit diadaptasikan dengan kondisi kandang selama 7 hari. Sebanyak 25 mencit dibagi menjadi 5 kelompok, masing-masing kelompok terdiri dari 5 ekor mencit. Sebelum diberikan perlakuan mencit sudah dipuasakan terlebih dahulu salama 6 jam tetapi tetap diberi minum. Kelompok 1 sebagai kelompok kontrol negatif diberikan minyak sebanyak $25 \mathrm{ml} / \mathrm{Kg}$ BB, kelompok 2 sebagai kontrol positif diberikan asam mefenamat dengan dosis $65 \mathrm{mg} / \mathrm{Kg} \mathrm{BB}$, kelompok 3,4 dan 5 sebagai kelompok uji diberikan ekstrak daunn kersen (Mutingia calabura L.) dengan dosis masing-masing $100 \mathrm{mg} / \mathrm{Kg} \mathrm{BB}, 125 \mathrm{mg} / \mathrm{Kg}$ BB dan $150 \mathrm{mg} / \mathrm{Kg}$ BB secara peroral. Pengujian aktivitas analgesik dilakukan pada menit ke-60 untuk melihat terjadinya efek analgesik setelah pemberian perlakuan. Pengujian dilakukan menggunakan induksi panas menggunakan hot plate dengan suhu $55^{\circ} \mathrm{C}$. Stopwatch dihidupkan pada saat mencit menyentuh permukaan hot plate dan diamati sampai mencit menunjukkan respon nyeri yang ditandai dengan gerakan melompat atau menjilat kakinya. Dicatat waktu timbulnya respon nyeri pada mencit yaitu ketika pertama kali mencit melompat atau menjilat kakinya.

Pengolahan dan Analisis Data. Data yang diperoleh diuji secara statistik dengan program SPSS 21 for windows menggunakan metode analisis Shapiro-Wilk yang dilanjutkan dengan uji One Way Anova dan Tukey Test.

\section{HASIL DAN PEMBAHASAN}

Pada penelitian ini dilakukan uji efektivitas analgesik esktrak etil asetat daun kersen menggunakan rangsangan panas dengan suhu konstan $55^{\circ} \mathrm{C}$ dikarenakan pada suhu tersebut mulai terjadi kerusakan jaringan akibat panas dan sensasinya berubah menjadi nyeri (Syamsudin dan Darmono, 2011). Hasil uji analgesik ekstrak daun kersen pada menit ke-60 menunjukkan bahwa kelompok kontrol positif memperoleh waktu paling lama dalam timbulnya respon nyeri, yang diikuti dengan kelompok perlakuan ekstrak dosis 150 $\mathrm{mg} / \mathrm{Kg} \mathrm{BB}, 125 \mathrm{mg} / \mathrm{Kg} \mathrm{BB}$, dan $100 \mathrm{mg} / \mathrm{Kg} \mathrm{BB}$, dapat dilihat pada Tabel 1.

Tabel 1. Waktu Munculnya Respon Nyeri Pada Mencit Putih Jantan

\begin{tabular}{|c|c|c|c|c|c|}
\hline \multirow{4}{*}{ Mencit } & \multicolumn{5}{|c|}{ Waktu (Detik) Munculnya Respon Nyeri } \\
\hline & \multirow{3}{*}{$\begin{array}{c}\text { Kelompok } \\
\text { Kontrol Negatif }\end{array}$} & \multirow{3}{*}{$\begin{array}{l}\text { Kelompok } \\
\text { Kontrol Positif }\end{array}$} & \multicolumn{3}{|c|}{ Kelompok } \\
\hline & & & Ekstrak & Ekstrak & Ekstrak \\
\hline & & & $100 \mathrm{mg} / \mathrm{Kg} \mathrm{BB}$ & $125 \mathrm{mg} / \mathrm{Kg} \mathrm{BB}$ & $150 \mathrm{mg} / \mathrm{Kg} \mathrm{BB}$ \\
\hline 1 & 10,24 & 36,2 & 25,1 & 38,65 & 39,4 \\
\hline 2 & 9,65 & 39,05 & 29,83 & 30,95 & 32,85 \\
\hline 3 & 11,32 & 35,5 & 27,08 & 35,34 & 36,75 \\
\hline 4 & 13,08 & 36 & 35,78 & 38,82 & 37,5 \\
\hline 5 & 9,43 & 39,55 & 19,05 & 33,23 & 35,78 \\
\hline Rata-rata & 10,74 detik & 37,26 detik & 27,37 detik & 35,40 detik & 36,46 detik \\
\hline
\end{tabular}

Tabel 2. Hasil Uji Normalitas

\begin{tabular}{lccl}
\hline \multicolumn{1}{c}{ Kelompok } & N & P & \multicolumn{1}{c}{ Keterangan } \\
\hline Minyak & 5 & 0,370 & Terdistribusi Normal \\
\hline Asam Mefenamat & 5 & 0,126 & Terdistribusi Normal \\
\hline Perlakuan dosis $100 \mathrm{mg} / \mathrm{Kg} \mathrm{BB}$ & 5 & 0,992 & Terdistribusi Normal \\
\hline Perlakuan dosis $125 \mathrm{mg} / \mathrm{Kg} \mathrm{BB}$ & 5 & 0,493 & Terdistribusi Normal \\
\hline Perlakuan dosis $150 \mathrm{mg} / \mathrm{Kg} \mathrm{BB}$ & 5 & 0,911 & Terdistribusi Normal \\
\hline
\end{tabular}


Dari hasil pengujian normalitas semua kelompok menunjukkan data terdistribusi normal dengan nilai $P>0,05$. Sehingga dapat dilanjutkan dengan pengujian homogenitas.

Tabel 3. Hasil Uji Homogenitas Munculnya Respons Nyeri Pada Menit ke-60

\begin{tabular}{ccc}
\hline Kelompok & $\mathbf{P}$ & Keterangan \\
\hline $\begin{array}{c}\text { Munculnya respon nyeri } \\
\text { pada menit ke-60 }\end{array}$ & 0,131 & $\begin{array}{c}\text { Homogen } \\
(p>00,5)\end{array}$ \\
\hline
\end{tabular}

Dari hasil uji homogenitas yang disajikan pada tabel 3. Menunjukan nilai $P=0,131$. Hal ini menunjukkan bahwa data kelompok kontrol negatif, kelompok kontrol positif dan kelompok perlakuan adalah sama dan homogen.
Tabel 4. Hasil Uji One Way Anova Munculnya Respons Nyeri pada menit ke-60

\begin{tabular}{cccc}
\hline Parameter & Kelompok & $\mathbf{N}$ & Nilai $\mathbf{p}$ \\
\hline Munculnya & Positif & 5 & \\
\cline { 2 - 3 } Respons & Negatif & 5 & \\
\cline { 2 - 3 } nyeri pada & P1 & 5 & \\
menit ke- & P2 & 5 & \\
\cline { 2 - 3 } 60 & P3 & 5 & \\
\hline
\end{tabular}

Berdasarkan hasil uji One Way Anova yang disajikan pada tabel 4. menunjukan nilai $P=0,001$ $(P<0,05)$, hal ini berarti terdapat perbedaan yang signifikan waktu pertama kali mencit menjilat kaki pada kelompok kontrol negatif, kelompok kontrol positif dan kelompok perlakuan.

Tabel 5. Hasil Pengujian Tukey Test Munculnya Respons Nyeri pada menit ke-60

\begin{tabular}{|c|c|c|c|}
\hline Kelompok & Kelompok & Signifikansi & Keterangan \\
\hline \multirow{4}{*}{$\mathbf{I}$} & II & 0.000 & Berbeda makna \\
\hline & III & 0.000 & Berbeda makna. \\
\hline & IV & 0.000 & Berbeda makna \\
\hline & $\mathrm{V}$ & 0.000 & Berbeda makna \\
\hline \multirow{4}{*}{ II } & 1 & 0.000 & Berbeda makna \\
\hline & III & 0.002 & Berbeda makna \\
\hline & IV & 0.914 & Tidak berbeda bermakna \\
\hline & V & 0.996 & Tidak berbeda bermakna \\
\hline \multirow{4}{*}{ III } & 1 & 0.000 & Berbeda makna \\
\hline & II & 0.002 & Berbeda makna \\
\hline & IV & 0.013 & Berbeda makna \\
\hline & V & 0.004 & Berbeda makna \\
\hline \multirow{4}{*}{ IV } & I & 0.000 & Berbeda makna \\
\hline & II & 0.914 & Tidak berbeda bermakna \\
\hline & III & 0.013 & Berbeda makna \\
\hline & V & 0.998 & Tidak berbeda bermakna \\
\hline \multirow{4}{*}{$\mathbf{V}$} & I & 0.000 & Berbeda makna \\
\hline & II & 0.996 & Tidak berbeda bermakna \\
\hline & III & 0.004 & Berbeda makna \\
\hline & IV & 0.998 & Tidak berbeda bermakna \\
\hline
\end{tabular}

Dari hasil uji Tukey Test yang disajikan pada tabel 5. menunjukan bahwa terdapat perbedaan yang signifikan terhadap waktu munculnya respon nyeri antara kelompok kontrol negatif dengan kelompok kontrol positif, dan kelompok perlakuan (ekstrak dosis $100 \mathrm{mg} / \mathrm{Kg}$ BB, $125 \mathrm{mg} / \mathrm{Kg} \mathrm{BB}$, $150 \mathrm{mg} / \mathrm{Kg}$ BB) dengan nilai signifikan secara berturut-turut 0,$000 ; 0,000 ; 0,000 ; 0,000$ ) . Hal ini dikarenakan kelompok kontrol negatif hanya diberi minyak yang tidak berkhasiat sebagai analgesik sedangkan kelompok kontrol positif diberikan asam mefenamat yang memiliki efek sebagai analgesik (Danugroho et.al.,2014). Pada kelompok kontrol positif dengan kelompok perlakuan ekstrak daun kersen dosis $100 \mathrm{mg} / \mathrm{Kg}$ BB menunjukkan nilai $p=0,002$ (sig < 0,005). Hal ini menunjukkan terdapat perbedaan bermakna pada waktu munculnya respon nyeri pada mencit. Selanjutnya, perbandingan kelompok kontrol positif dengan kelompok perlakuan ekstrak daun kersen dosis 
$125 \mathrm{mg} / \mathrm{Kg}$ BB dan $150 \mathrm{mg} / \mathrm{Kg}$ BB menunjukkan nilai p secara berturut-turut 0.914 dan 0,996 . Hal ini menunjukkan tidak terdapat perbedaan bermakna pada waktu munculnya respon nyeri pada mencit. Adanya efek analgesik pada ekstrak daun kersen diduga karena adanya kandungan metabolit sekunder pada ekstrak etil asetat daun kersen.

Berdasarkan hasil penelitian Syahara (2019) mengenai skirining fitokimia, kandungan metabolit sekunder yang terdapat pada ektrak etil asetat daun kersen menunjukkan adannya senyawa flavonoid, saponin, tanin, triterpen, steroid, polifenol, alkaloid dan antrhoquinon. Kandungan senyawa kimia golongan saponin dan flavonoid yang terkandung dalam daun kersen berfungsi sebagai anti-inflamasi, antiseptik, mengurangi rasa nyeri mengatasi rasa sakit apabila terjadi pendarahan dan mengurangi inflamasi pada luka. Flavonoid pada daun kersen juga memiliki aktivitas antioksidan yang sangat tinggi dengan nilai $I_{50} 14,4873 \mu \mathrm{g} / \mathrm{ml}$.

Efektivitas flavonoid sebagai analgesik dilakukan dengan menghambat kerja enzin siklooksigenase, sehingga akan mengurangi produksi prostaglandin oleh asam arakidonat yang dapat mengurangi rasa nyeri, selain itu flavonoid juga dapat menghambat degranulasi neutrophil sehingga akan menghambat pengeluaran sitokin, radikal bebas, serta enzim yang berperan dalan peradangan (Sentat dan Pangestu, 2016).

\section{SIMPULAN}

Berdasarkan hasil penelitian dapat disimpulkan bawah ekstrak etil asetat daun kersen (Mutingia calabura L.) dosis $125 \mathrm{mg} / \mathrm{KgBB}$ efektif sebagai analgesik pada mencit jantan (Mus musculas L.).

\section{DAFTAR PUSTAKA}

Danugroho, E. S. dan N. R. Widyaningrum, 2014. Aktivitas Analgesik Infusa Daun Kersen (Muntingia Calabura) dengan Hewan Uji Mencit Ras Swiss. Indonesian Journal on Medical Science, Vol. 1 No. 2.

Jahwa, J. Y., (2016). Uji Efek Analgesik Ekstrak Etanol 70\% Rimpang Temulawak (Curcuma xanthorrhiza Roxb) pada Mencit (Mus musculus) Jantan Galur Swiss yang diinduksi Nyeri Asam Asetat Dengan Metode Geliat (Writing Testi). Universitas Muhamadyah Surakarta.

Sentat, T., dan Pangestu, S., (2016). Uji Efek Analgesik Ekstrak Etanol Daun Kersen (Mutinga calabura L.) Pada Mencit Putih Jantan (Mus musculas) Dengan Induksi Nyeri Asam Asetat. Jurnal Ilmiah Manuntung, 2 (2).

Suryaningsih, I. D.A., Bodhi, W., Lolo, W.A., (2018). Uji Efek Analgesik Ekstrak Etanol Daun Kersen (Mutingia calabura L.) pada Mencit (Mus musculus). Pharmacon Jurnal ilmiah Farmasi- Unsrat, 7(3).

Syahara, S., Siregar, Y.F., (2019). Skrining Fitokimia Ekstrak Etanol Daun Kersen (Mutingia calabura L.). Jurnal Kesehatan IImiah Indonesia (Indonesia Health Scientific Journal), 4 (2).

Syamsudin dan Darmono. (2011). Buku Ajar Farmakologi Eksperimental. Jakarta: Universitas Indonesia. Hal 12.

Tjay, T.H. \& Rahardja, K. 2007. Obat-obat Penting. Edisi keeenam, 570-572. PT. Elexx. Media Kompuntindo. Jakarta 